\author{
T.B. Kenzhebaeva ${ }^{l}$, J.ZH. Sakenov ${ }^{l}$, Y.A. Shnaider ${ }^{l}$, \\ A.D. Zhantemirova ${ }^{l}$, B.M. Zhaparova ${ }^{l}$, A.V. Lyuft ${ }^{l}$, \\ A.N. Akhmuldinova ${ }^{l}$ \\ ${ }^{l}$ Non-commercial joint-stock company «Pavlodar pedagogical University», \\ (Pavlodar, Republic of Kazakhstan)
}

\title{
SOCIALIZATION IN THE ORPHANAGE
}

\begin{abstract}
.
The article substantiates the process of socialization of orphans and children left without parental care, who are brought up in specialized state institutions - orphanages. The essence of socialization of orphans and children without parental care has been clarified. The pedagogical conditions of socialization of orphans and children without parental care are revealed and theoretically substantiated. Evaluation criteria and indicators of socialization of orphans and children without parental care have been developed, adequate methods of socialization of orphans and children without parental care have been selected. The technology of socialization for orphans and children without parental care has been developed. In the course of the experimental work, the effectiveness of the implementation of the pedagogical conditions for the socialization of orphans and children without parental care was determined. The research results are recommended for practical use in orphanages in the process of socialization of orphans and children without parental care.
\end{abstract}

Keywords: socialization, orphanage, orphans, development, personality.

\section{Т.Б. Кенжебаева ${ }^{l}$, Д.Ж. Сакенов ${ }^{l}$, Е.А. Шнайдер ${ }^{l}$, А.Д. Жантемирова ${ }^{l}$, Б.М. Жапарова ${ }^{l}$, А.В. Люфт ${ }^{l}$, А.Н. Ахмульдинова ${ }^{1}$ \\ ${ }^{1}$ Коммерииялық емес акиионерлік қ̧овам Павлодар педагогикальқ университеті (Павлодар, Қазақстан)}

\section{БАЛАЛАР ҮЙІНДЕГІ ӘЛЕУМЕТТЕНДІРУ}

\begin{abstract}
Аңъдатпа
Мақалада мамандандырылған мемлекеттік мекемелерде - балалар үйінде тәрбиеленіп жатқан жетім балалар мен ата-анасының қамқорлығынсыз қалған балаларды әлеуметтендіру процесі негізделген. Жетім балалар мен ата-анасының қамқорлығынсыз қалған балаларды әлеуметтендірудің мәні нақтыланды. Жетім балалар мен ата-анасының қамқорлығынсыз қалған балаларды әлеуметтендірудің педагогикалық шарттары ашылды және теориялық тұрғыдан негізделген. Жетім балалар мен ата-анасының қамқорлығынсыз қалған балаларды бағалау критерийлері мен индикаторлары әзірленді, жетім балалар мен ата-анасының қамқорлығынсыз қалған балаларды әлеуметтендірудің барабар әдістері таңдалды. Жетім балалар мен ата-анасының қамқорлығынсыз қалған балаларды әлеуметтендіру технологиясы жасалды. Эксперименттік жұмыс барысында жетім балалар мен ата-анасының қамқорлығынсыз қалған балаларды әлеуметтендірудің педагогикалық шарттарын іске асырудың тиімділігі анықталды. Зерттеу нәтижелері жетім балалар мен ата-анасының қамқорлығынсыз қалған балаларды әлеуметтендіру процесінде балалар үйінде практикалық қолдануға ұсынылады.
\end{abstract}

Tүйін сөздер: әлеуметтену, балалар үйі, жетім балалар, даму, тұлға.

\section{СОЦИАЛИЗАЦИЯ В ДЕТСКОМ ДОМЕ}

\author{
Т. Б.Кенжебаева ${ }^{l}$, Д.Ж. Сакенов ${ }^{l}$, Е.А. Шнайдер ${ }^{l}$, А.Д. Жантемирова ${ }^{l}$, Б.М. Жапарова ${ }^{l}$, \\ А.В. Люфм ${ }^{l}$, А.Н. Ахмульдинова ${ }^{l}$ \\ ${ }^{1}$ Некоммерческое акиионерное общество «Павлодарский педагогический университет» \\ (Павлодар, Казахстан)
}

\section{Аннотация.}

В статье обоснован процесс социализации детей-сирот и детей, оставшихся без попечения родителей, воспитывающихся в специализированных государственных учреждениях - детских 
домах. Уточнена сущность социализации детей-сирот и детей, оставшихся без попечения родителей. Выявлены и теоретически обоснованы педагогические условия социализации детейсирот и детей, оставшихся без попечения родителей. Разработаны критерии оценки и показатели социализации детей-сирот и детей, оставшихся без попечения родителей, выбраны адекватные методы социализации детей-сирот и детей, оставшихся без попечения родителей. Разработана технология социализации детей-сирот и детей, оставшихся без попечения родителей. В ходе экспериментальной работы определена эффективность реализации педагогических условий социализации детей-сирот и детей, оставшихся без попечения родителей. Результаты исследования рекомендованы к практическому использованию в детских домах в процессе социализации детей-сирот и детей, оставшихся без попечения родителей.

Ключевые слова: социализация, детский дом, дети-сироты, развитие, личность.

Introduction. The process of socialization for orphans and children left without parental care, who are brought up in specialized state institutions, is excursive, pedagogically distorted, caused by maternal and paternalistic (paternal) deprivation, deformation of parent-child relations, and the specifics of upbringing in closed institutions.

The problem of the development of the personality of orphans is the subject in the works of T.I. Yuferev [1], N.N. Tolstykh, A.M. Prikhozhan [2], J. Langmeier, Z. Matejcek [3], V.S. Mukhina [4]; interrelation of deviations of children from institution of adoption with disturbance of the process of gender identification (I.A. Furmanov, A.A. Aladyin, N.V. Furmanova [5]). The works of famous scientists S.K. Thompson [6], G. Kelly [7], I.S. Kon [8] devoted to the problems of gender and gender relations, or domestic scientists (A.K. Kisymova [9], M.P. Kushnir [10]), Ribakova L.A., Parfilova G.G., Karimova L.S. [11], Sakenov J.J., Shnaider E.A. [12]; [13]. Features of socialization of children living outside the family are studied in the works of L.G. Zhedunov, Posysoev N.N. [14]; N.G. Tikhontsev [15], G. Makashkulova [16].

The basic conditions of the socialization and individualization processes of a person are laid down in the concept of cultural and historical development of higher mental functions, developed in a scientific school (L.S. Vygotsky [17], A.N. Leontiev [18], L.F. Obukhova [19]), where the development of the child takes place in the process of interiorization of cultural and historical experience and social relations, in which the adult is a medium of this experience and the most important source of development. According to the concept of socialization by A.V. Mudrik [20], the family is a priority micro-factor and plays a decisive role at any stage of a child's development. At the same time, the role of the family, especially at an early stage of development, cannot be compensated for by other social institutions.

Theoretical and methodological analysis of the research problem led to the conclusion that the socialization of orphans takes place in a changed social situation of development, which is formed as a result of the absence of a parental family.

Studies of many teachers and psychologists show that graduates of the institution of adoption are characterized by low adaptability in public life. The social situation of child development in institution of adoption is characterized by deprivation of the need for parental love, lack of deep emotional contacts with others and difficulties in the implementation of intimate-personal communication. The socialization of an orphan of a closed institution takes place in specific severe conditions of restriction, suppression of the child's spontaneous activity.

One of the characteristic signs of our time is the growth in the number of orphans and children left without parental care. A child brought up in an orphanage has certain characteristics in the mental and emotionally personal spheres, as well as in interpersonal relationships with peers and adults, which is largely determined by the factor of the impossibility of full realization, the innate need to communicate with loved ones. Today, it is very important to search for such pedagogical means that can solve many problems of the social formation of orphans in the institution of adoption.

Thus, the problem of our research is determined by the contradictions between the need of modern upbringing practice for effective pedagogical support of the process of socialization of orphans in an orphanage and the low level of scientific elaboration of the topic.

The relevance of the research problem made it possible to formulate the purpose of the research is to identify the specifics of the socialization of orphans and to determine the ways of effective pedagogical support of this process.

Methods. The following research methods were used: theoretical: analysis of the literature on the investigated problem of identification, theoretical substantiation of the pedagogical conditions of socialization of children in an orphanage, this method was chosen as a method of accumulation, 
systematization of scientific material characterizing the process under study, its comprehension, choice of the direction of research, determination of the goal, development of methodology and research methods; the method of developing the theoretical provisions of the research was chosen as a way to systematize the problem of identifying, theoretically substantiating the pedagogical conditions of socialization of children in an orphanage; empirical methods: questioning, testing, conversation, observation; pedagogical experiment, analysis of documentation, study and generalization of experience, the method of expert assessments, self-assessment, the method of statistical processing of the results obtained (qualitative and quantitative analysis of the data obtained).

Results. We see socialization in an orphanage as a process of establishing relationships between orphans and society based on the implementation of an individual strategy of social learning, selfknowledge and self-realization of the individual, providing social knowledge, socially oriented motives and social experience of the personality.

The living environment of orphans in orphanages, due to both objective and subjective reasons, has its own limitations, which do not allow to fully solve the problems of their successful socialization, namely, limitation of contacts with the outside world, separation from the family, family ties, the predominance of collective forms of organization life activities over individually oriented, the constancy of the microsocial environment, the subject-spatial environment, the lack of conditions for the formation of ideas about various social roles, the world of professions, the lack of opportunities to form full-fledged connections and relationships with the outside world, limitation of the possibility of independent obtaining information about the world.

In connection with these problems, the socialization of orphans, children left without parental care has a number of specific features. We carried out a quantitative study comparing the characteristics of children from orphanages and children raised in a family. The study was conducted in October, 2020 in educational institutions and orphanages in Pavlodar. The objects of research were children in their teens. This is due to the fact that at this age the basic skills of life have already been formed, the foundations of an independent life are being developed, the foundations of intimate and personal relationships are laid. The method of mass questionnaire was used as a method of collecting information. The attitude of children and teachers was considered in the context of this study, and the relationship with educators was also considered among children in orphanages. Most children treat their teachers well and perceive them as authorities, adopt some of their traits, listen to them, try to get closer to them. Kindness (69\%) and understanding $(61.9 \%)$ were selected as priority qualities by the majority of children in the orphanages. The most frequently chosen qualities among children brought up in a family are a sense of humor (63.6\%), kindness $(54.5 \%)$ and understanding (55.7\%). For the children of the orphanage, it is most important to receive positive emotions and support from teachers and educators, since they do not have opportunities, or they are limited, in receiving support from relatives and friends, orphans try to get closer to teachers to meet the needs for productive interpersonal relationships between a child and an adult, they need advice to help them cope with a problem. Inmates of orphanages receive the main assistance from teachers $(41.4 \%)$ and child care workers $(79.8 \%)$, and school students from relatives $(59.2 \%)$ and classmates $(55.1 \%)$, which is a reflection of their social status. Children in orphanages also ask for help from school teachers, but since they spend less time with them, they are not their main assistants. It is the child care workers who replace their parents for children in difficult life situations, they provide basic help and support. The main issue under discussion between a teacher, care worker and children is the issue of teaching children, since this is the main professional function of a teacher. But at the same time, some of the children do not feel embarrassed when contacting teachers about their personal life, which means that teachers inspire their confidence and help them to the best of their ability. Children of orphanages turn to teachers a little more often than family children, asking them for advice on the choice of a "soul mate" or friends. This is explained by the fact that for family children such advisors are relatives, in whom the degree of trust is somewhat higher. As for care worker, children of orphanages treat them extremely positively, trust them with their "secrets", consult with them about both educational activities and interpersonal relationships. Talking about relationships with peers, we can say that most of them perceive them as friends. Communication is the leading activity for children in their teens. According to the respondents, they have 7 or more friends. Orphans spend most of their time together and get used to each other, they perceive themselves as one whole, children are united by the common problem of the absence of a normal family and this brings them together, makes them closer to each other. About family children, we can say that, due to their age, they treat their peers positively and perceive them as best friends. Children raised in a family also differ in that their social circle is much wider than that of orphans, whose social circle is limited by the inmates and employees of the orphanage. 
Children are ready to help their friend "no matter what" (67\% - children from orphanages, $60 \%$ - children raised in a family). For orphans, a group of their friends is a way of being, and in a group it is necessary to help each other in order to maintain a comfortable environment. The socialization of children brought up in a family is more complete and consistent, children gradually acquire all the necessary skills. The socialization of children in orphanages is much slower and in its process children cannot fully acquire all the necessary skills, values, and competencies that they need in life. We came, therefore, to the conclusion that it is necessary to develop conditions for the successful socialization of children in orphanages, which ensure the appropriation of the necessary values, norms, skills and competencies.

Discuss. The novelty and originality of our work is obvious in the fact that, in contrast to the studies of Greenberg D. (2007), Bhola H.S. (1995), Infante I. (2000), Olesova, A.P. (2013), we have proved that the criterial assessment of the socialization of an orphan should be based on such personal properties as emotional stability, sociability, a high level of self-control when communicating in a team, calmness, and trustfulness. The decisive pedagogical condition that allows us to talk about the successful socialization of a child in an orphanage is satisfaction with their position, their work, relationships with adults and peers.

In an independent life, orphans will have to enter into social relations, which requires the development of social skills and personal skills, such as responsibility, the ability to make choices and work in cooperation. It is necessary to technologically diversify the environment and forms of social life. Since we are talking about an orphan child, it is here that a developing environment should be created that maximally contributes to the expansion and deepening of their socialization in three main areas: activity, communication, self-knowledge. This will largely be facilitated by the active participation of orphans in the work of the children's organization under the pedagogical condition of joint activities of children and adults, i.e. cooperation. Technologically justified is the process of giving children the opportunity to offer their options for future activities, arrangement of life and everyday life, design of classrooms and a courtyard, and come to their aid, which in turn is an important pedagogical condition for the socialization of children in an orphanage.

Conclusion. Teachers and child caregivers and authority bodies competent in this area should pay attention to the development of such personality traits that ensure success in modern life. There are communicative culture, the ability to follow behavioral models adequate to the situation; the ability to make an informed and responsible choice; the ability to work in a group, team; the ability to be creative, the ability to solve problem situations for the socialization of orphans, the formation of social competence of a graduate of an orphanage and an adequate assessment of oneself and others in society. These are pedagogical aspects that should be strengthened in the educational process, both in the classroom and outside the classroom. Summarizing what has been said, we should highlight the main characteristic social traits of children brought up in orphanages. Children in orphanages are not able to establish constructive, emotionally appropriate relationships with other people. They have an inherent aggressive attitude towards other people. They do not accept themselves as a person, they lack a set of value orientations, personal qualities, knowledge and skills. Orphans, accustomed to dependence, do not know how to take care of themselves, of their future, they know that they have no one to help. They are not prepared for independent living. Among the main pedagogical directions for improving the socialization of orphans, we single out the formation of a positive attitude to work, ensuring the productivity of social contacts and the formation of a clear life perspective. Not only employees of social institutions, teachers, authority bodies, but also society as a whole should be interested in this in order to maintain social stability and harmonious development of society.

\section{References}

1. YuferevT.I. Osobennosti formirovaniya psihologicheskogo pola u podrostkov, vospityvayushchihsya $v$ sem'e $i$ v internate // Vozrastnye osobennosti psihicheskogo razvitiya detej. M., 1982. P. 122-131.

2. TolstykhN.N., PrikhozhanA.M. Psihologicheskij portret rebenka iz detskogo doma. Vyreshiliusynovit'rebenka. M.: Drofa. 2001. P.108-188.

3. Langmeier J., Matejcek Z. Psychological Deprivation in Childhood. Prague: Avicenum, MedicalPublishingHouse, 1984. P. 334.

4. MukhinaV.S. Deti detskih domov $i$ shkol-internatov o sebe (retrospektivnaya refleksiya, obrashchennost' $v$ nastoyashchee i budushchee). Lishennye roditel'skogo popechitel'stva / Red. sost. V.S. Muhina. M.: Prosveshchenie, 1991. P. 260.

5. FurmanovI.A., AladyinA.A., FurmanovaN.V. Psihologicheskaya osobennosti detej, lishennyh roditel'skogo popechitel'stva. Mn.: Tesey, 1999. P. 160. 
6. Thompson S.K. Gender labels and early sex-role development//Child Development. - 2005.-Vol. 46. - R. 339-347.

7. KellyG. Vozrastnye osobennosti seksual'nosti // Osnovy sovremennoj seksologii. - SPb.: Piter, 2000. - P. 222-281.

8. KonI.S. Seksual'naya kul'tura 21 veka // Pedagogika. - No.4. - 2003. - P. 3-15.

9. KisymovaA.K. Қаzақ̆tyщ halyқ̧tyқ pedagogikasy arķyly oқ̧ushylarza adamgershilik - zhynystyқ̧tərbie beru: avtoref. ... kand. ped. nauk: 13.00.01-Almaty: ASU, 1994. - P. 21.

10. KushnirM.P. Polovoe vospitanie detej v sem'e. Kniga dlya roditelej: Ucheb.posobie. - Karaganda: LLP «SANA T-Poligrafiya», 2004. - 122 p.

11 Ribakova L.A., Parfilova G.G., Karimova L.S. Evolution of communicative competence in adolescents growing up in orphanages.LifeSci J 2014;11(12s):114-117] (ISSN:1097-8135). http://www.lifesciencesite.com.

12. Sakenov J.J., Shnaider E.A. Gendernoevospitaniedetej-sirot. - Pavlodar: PSPI, 2016. - 143 p.

13. Sakenov J.J., Shnaider E.A., Jantemirova A.D, Jantemirova F.D. Vospitaniedetejvdetskomdome. Pavlodar: PSPI, 2017. - 156 p.

14. Zhedunova L.G., Posysoev N.N. and others. Problemy socializacii detej sirot. - Yaroslavl, 1997.

15. Tikhontseva N.G. Osobennosti gendernoj socializacii detej-sirot, vospityvayushchihsya v priemnoj sem'e i v detskom domell Molodoj uchenyj. - 2009. - No. 6 (6). - P. 154-159.

16. MakashkulovaG. Balalar yjindegi tərbielenushilerdiң̧ psihikalyқ erekshelikteri. // Kazaқstan mektebi, 11-12/2005, p. 52-53.

17. Vygotsky L.S. Myshlenie i rech'. Problemy psihologicheskogo razvitiya rebenka. Izbrannye pedagogicheskie issledovaniya. - M: APN, 1956.

18. Leontiev A.N. Deyatel'nost'. Soznanie. Lichnost'. - M: APN, 1977.

19. Obukhova L.F. Detskaya psihologiya: teorii, fakty, problemy M.: Trivola, 1998. -352 p.

20. Mudrik A.V. Social'no-pedagogicheskie problemy socializacii. M.: MSPU, 2017. -268 p. 